\title{
PHYSICAL EDUCATION TEACHERS' RELATIONSHIP WITH UNIVERSITY AS SCIENTIFIC, EDUCATIONAL AND SOCIAL INSTITUTION
}

\author{
Giedrė Rastauskiené $\dot{1}^{1}$, Vilija Kriauzaité ${ }^{2}$, Ilona Tilindiené ${ }^{1}$ \\ Lithuanian Academy of Physical Education', Kaunas, Lithuania \\ Lithuanian University of Health Sciences ${ }^{2}$, Kaunas, Lithuania
}

\begin{abstract}
Research background and hypothesis. Academic environment necessitates university teachers to carry out three essential professional functions: scientific, educational and social, and to gain such professional self-perception which is desirable for the individuals themselves and are also rooted in the cultural perception of the academic community and matches the expectations of modern society.

Research aim was to reveal the relationship between university physical education teachers and the university as scientific, educational and social institution.

Research methods. The study employed a non-standardized questionnaire drawing upon the survey of L. Paterson et al. (2003) about the expression of democratic intellect in Scotland and England. The attitudes of the research participants were interpreted using nonparametric statistical methods.

Research results. Educational activities remained the major priority of professional activities at the beginning of professional careers. The lower priority was ascribed to scientific and social functions.

Discussion and conclusions. Physical education teachers carried out three essential professional functions: scientific, educational and social giving the major priority to the educational function: preparation of textbooks, course books, worksheets, courses, vocational events, updating their professional knowledge. Physical education teachers are also oriented towards applied research which is related to scientific function at the university - preparation of doctors of science.
\end{abstract}

Keywords: higher education, academic profile, professional functions of teachers.

\section{INTRODUCTION}

$\Lambda$ cademic community in the specific professional field determines the origin and functioning of each professional community including physical education. Aiming at achieving its existential goals, it fosters cultural values and accumulates professional experience while educating new physical education specialists, providing professional services and creating institutional systems of physical activity. In this way, academic community is the background of a certain professional community and its transformations and survival.

University teachers as a professional community are defined as an informal group of teachers in related professions. They gain new knowledge dealing with common academic work problems and finding their solutions (Stake, 1998). Even during the first year of their studies they gain a feeling and habits of belonging to an academic community. This is especially noticeable during doctoral studies, and particularly after the acquisition of scientific degree or when they are employed in a higher education institution (Becher, 1989). In social sciences there is abundance of publications concerning the functions of university teachers (Braskamp, Ory, 1994; Austin, 1996; Nixon, 1996; Välimaa, 1998; De Simone, 2001; 
Paterson, 2003; Krabi, 2005). Publications show that academic culture necessitates university teachers to carry out three essential professional functions: the scientific, educational, and social, as well as to develop professional self - awareness. It also corresponds to the expectations of contemporary society. Professional identity of university teachers is expressed not only in perception of professional role (who are they), but also in professional activity - what they do and how they combine teacher's essential functions (Austin, 1996; De Simone, 2001; Harris, 2005; Krabi, 2005).

The studies of academic community, its origin, scientific profile and the analysis of its social environment cover a wide range of contexts of the communities involved in academic practice. The scientific profile of the academic community helps understand the causes of science evolution (Kuhn, 1962, 1970), culture and identity of disciplinary communities, (Becher, 1989; Scheff 1995; Austin, 1996; Braxton, Hargens, 1996; Ylijoki, 2000; Harris, 2005; Churchman, 2006). During the last decade in Lithuania scientists focused on the following aspects of physical activity profile: sports science paradigm (Skurvydas, 2008), functions of sports science and expansion of sports science (Skurvydas 1996; Poderys, 2002; Poderys, Visagurskiene, 2004). In Lithuanian higher education institutions research is carried out about the tendencies of physical education (Tamošauskas, 2007) including university teachers' approach to the institutional activity and academic values (Kardelis et al., 2007), value orientations of teachers at the Lithuanian Academy of Physical Education (Šukys et al., 2006).

The formation of communities interested in scientific practice has been examined theoretically. However, interdisciplinary sciences such as sports science or health sciences have received too little attention tough they are interconnected with the functions of university teachers. There are not many surveys on the interrelations of physical education teachers and the university. Academic community dealing with sport science practice is comparatively a very young community. It started functioning markedly in the middle of the twentieth century due to the growth in basic sports science disciplines. It was also due to an increased interest in modern public health and sports needs. This situation requires empirical evidence. Thus, our research questions were as follows: 1) What are the dominant attitudes of physical education teachers performing their professional activities in the universities? 2) What professional functions are recognized and carried out by teachers in the area of physical education? 3) What factors determine major recognition of physical education teachers' professional functions? The aim of the research was to reveal Lithuanian university physical education teachers' professional relationship with the university as a scientific, educational and social institution.

\section{RESEARCH METHODS}

The research sample included 78 respondents (60 men and 60 women). All research participants were employed in physical education departments in Lithuanian institutions of higher education (Lithuanian University of Health Sciences, Lithuanian University of Agriculture, Klaipeda University, Mykolas Romeris University, Vilnius University, Vytautas Magnus University, and Vilnius Pedagogical University). There were also 42 respondents from the Lithuanian Academy of Physical Education engaged in individual sports, fitness and gymnastics. Even 45 respondents had a scientific degree; 71 persons did not have any academic title. This sample represented the population of about 200 Lithuanian university physical activity specialists. The data were collected in 2009.

In preparing a nonstandard research questionnaire we applied L. Paterson's (2003) test of the expression of democratic intellectualism in Scotland and England. We added our own statements as well. We divided them into the following sections of professional roles: the scientific function, educational function and social function. We elaborated on an expression of the professional functional priorities of physical education teachers. We tried to find out if one function was not given a higher priority compared to the others. By expressing their opinions respondents evaluated each given statement in points by selecting one of four possible options. From 1 - it does not matter at all, up to $4-$ it is very important. They were standardized in rage of the values from -1 to 1 . In this way the following formula was used to calculate standardized rate I:

$$
I=\frac{-1 \times n_{1}-0.5 \times n_{2}+0.5 \times n_{3}+1 \times n_{4}}{n_{1}+n_{2}+n_{3}+n_{4}}
$$

where $n_{1}$ - the number of subjects who evaluated the statement as unimportant (1); $n_{2}$ - the number of subjects who evaluated the statement as not very important (2); $n_{3}$ - number of subjects who evaluated the statements fairly important (3); and 
$n_{4}-$ who evaluated the statement as very important (4), $-1 ;-0.5 ; 0.5 ; 1$ - factors of the evaluation score. Interpretation of the standardized index is shown in Table.

Table. Interpretation of the standardized index I

\begin{tabular}{|l|l|}
\hline \multicolumn{1}{|c|}{ Range of index I } & \multicolumn{1}{c|}{ Assessment } \\
\hline From 0.50 to 1.00 & Very important \\
\hline From 0.00 to 0.49 & Quite important \\
\hline From -0.01 to -0.49 & Not so much important \\
\hline From -0.50 to -1.00 & It makes no difference \\
\hline
\end{tabular}

For the analysis of the statistical data we applied Chi-square test. Comparable samples have been chosen according to the statistical survey rules of W. C. VanVoorhis and L. B. Morgan (2001). The differences were statistically significant when the probability for the error was not higher than $5 \%$ $(\mathrm{p}<0.05)$. In this study the independent variables were scientific degree of the respondents and training professionals of physical education and sports at LAPE.

\section{RESEARCH RESULTS}

Figure 1 shows a dispersion of standardized indicators of the scientific function expressed in the attitudes of the research participants.

Figure 1 shows that, despite of the scientific degree held by Lithuanian universities physical education teachers, one third of them agreed on the importance of university contribution to the regional or the whole country's economical development. Almost half of the respondents thought that it was very important to carry out fundamental research. However, depending on qualification $\left(\div^{2}=10.9(3) ; p=0.02\right)$, points of view about the fundamental investigations differ. The importance of basic research $(I=0.68)$ is more emphasized by people without scientific degree than by their certified colleagues $(\mathrm{I}=0.56)$. Respondents favorably evaluated planning research methodologies and innovations for commercial purposes. However, only one fifth of the respondents evaluated this type of activity as a very important. Development of applied research is most supported by Lithuanian teachers of physical education.

Figure 2 shows a dispersion of the standardized indicators for the educational functional attitudes of Lithuanian high school physical education teachers.

Figure 2 illustrates that all components of educational function are considered as very important. In opinion of two - thirds of physical education teachers, training doctors of science is a very important function of education at the university. More than half of the respondents thought that continuous education was also very important. Vocational events for students were considered as important by one third of the respondents. Only one tenth of the respondents considered students' academic ambitions and general competences as unimportant part of the university education.

Respondents' attitudes differed about the statement that a university should prepare practitioners who are able to compete in the labor
Figure 1. Dispersion of standardized indicators of scientific functions expressed by the attitudes of university teachers

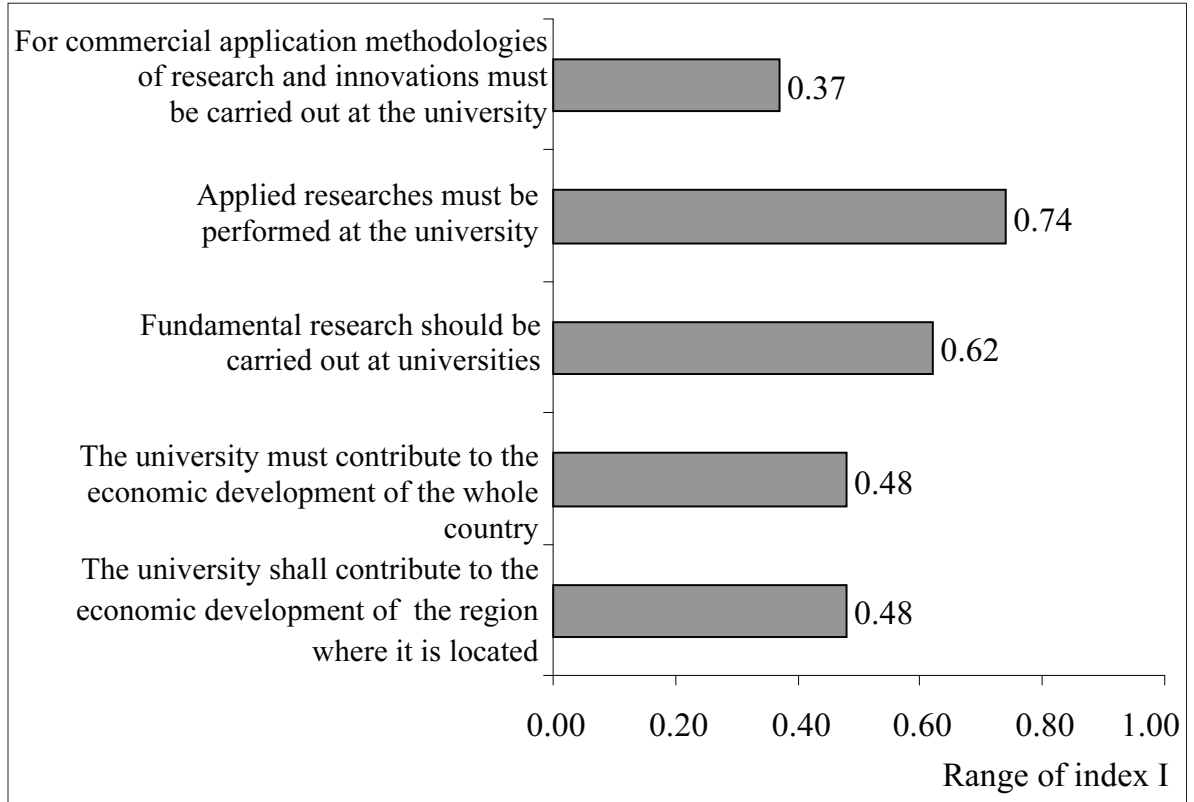




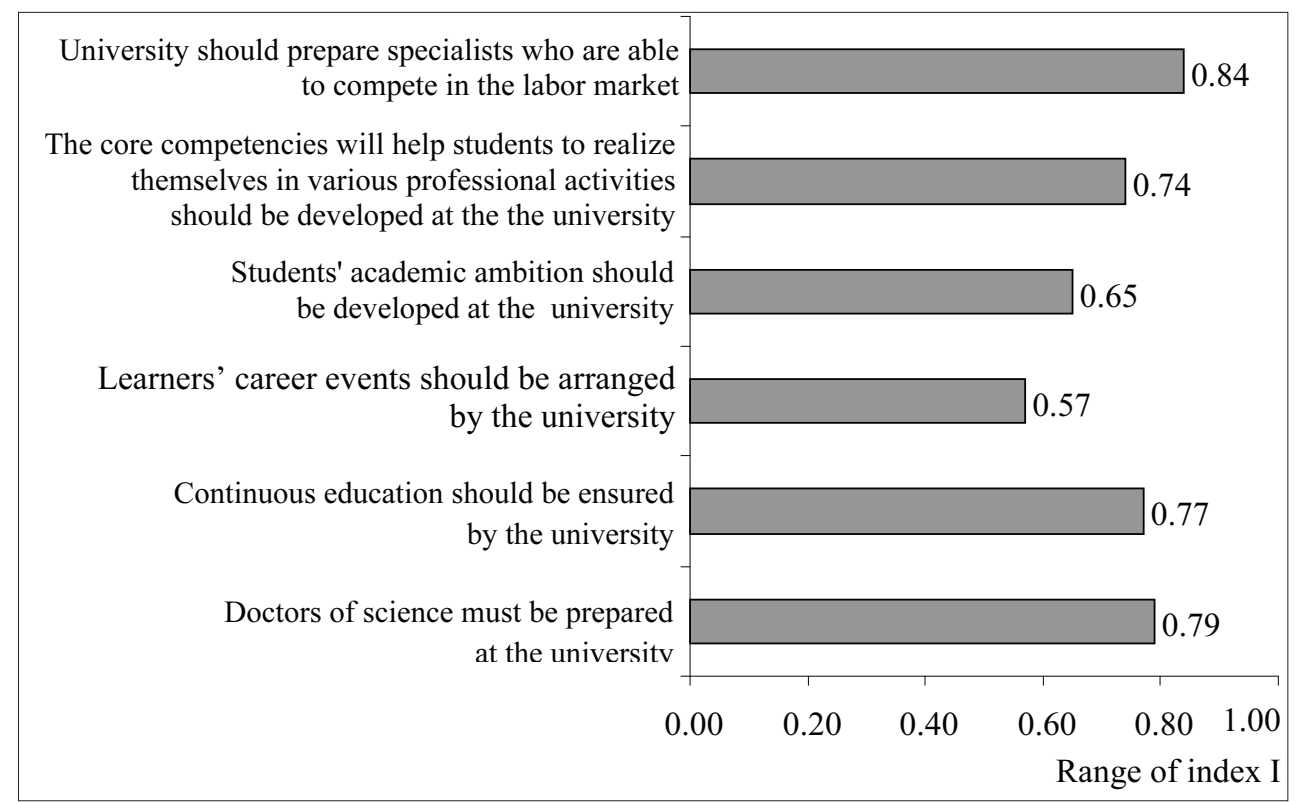

Figure 2. Dispersion of standardized indicators for attitudes of the educational function of university teachers

market. Here we observed a link with the university profile $\left(\dot{\div}^{2}=11.9(2) ; \mathrm{p}=0.03\right)$. Physical education teachers of the Lithuanian Academy of Physical Education more disagreed with the statement $(I=0.85)$ than teachers in other universities $(\mathrm{I}=0.87)$.

Except for the negative attitude towards the management of the university as a profit organization, respondents evaluated all social functions as very important (Figure 3).

As it is indicated in Figure 3, a quarter of surveyed physical education teachers did not completely agree that the university should be managed as a profit-making organization; nearly half of participants fully agreed that university must be autonomous. As the research shows, depending on the profile of a university $\left(\div^{2}=8.9(3) ; \mathrm{p}=0.03\right)$, autonomic attitudes were different. Physical education teachers at the Lithuanian Academy of Physical Education $(I=0.62)$ more emphasized this statement in comparison with the teachers at other universities $(\mathrm{I}=0.60)$.

We did not find significant differences in the attitudes depending on the competence

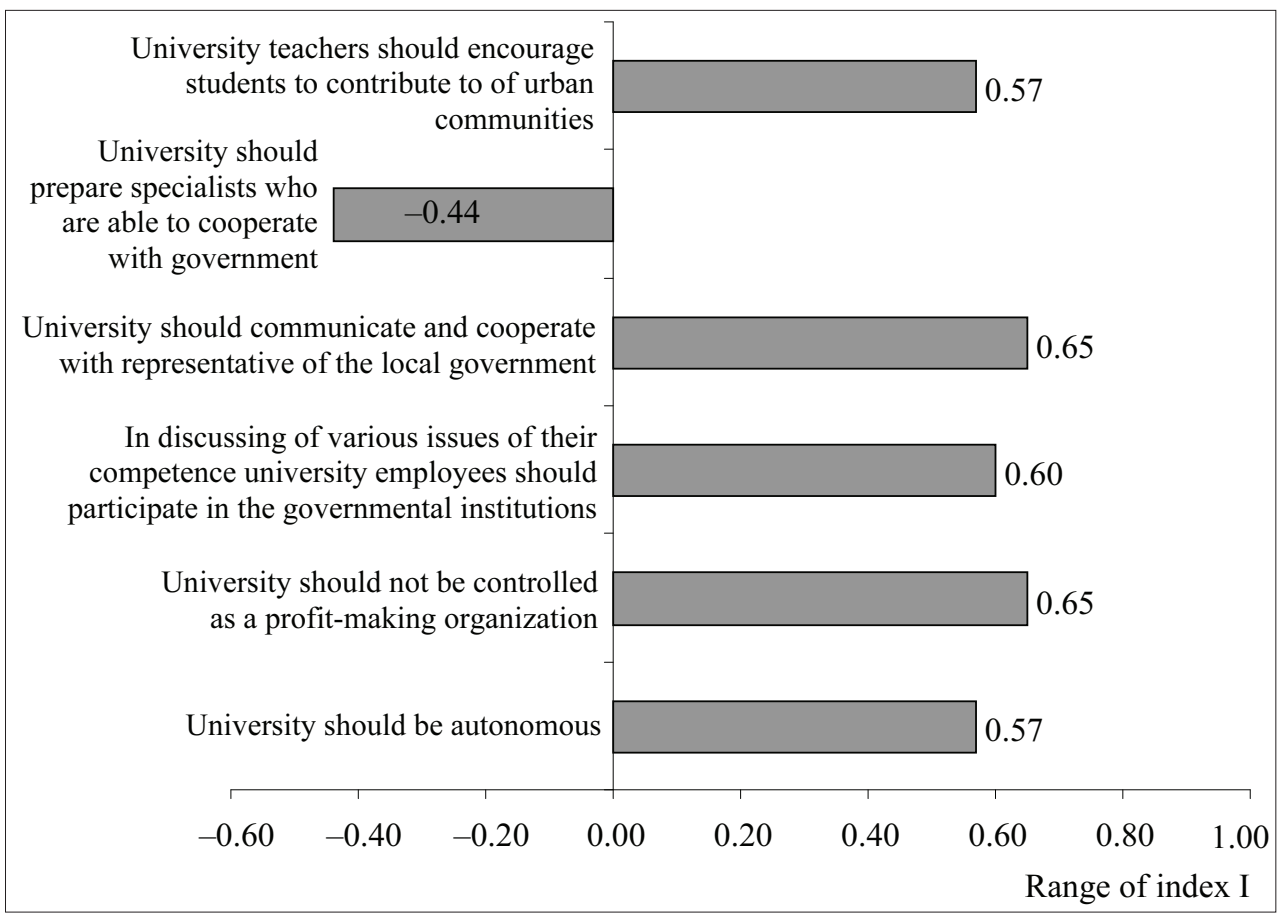

Figure 3. Dispersion of standardized indicators of attitudes to university social functions 
Figure 4. Dispersion of priorities in professional activities

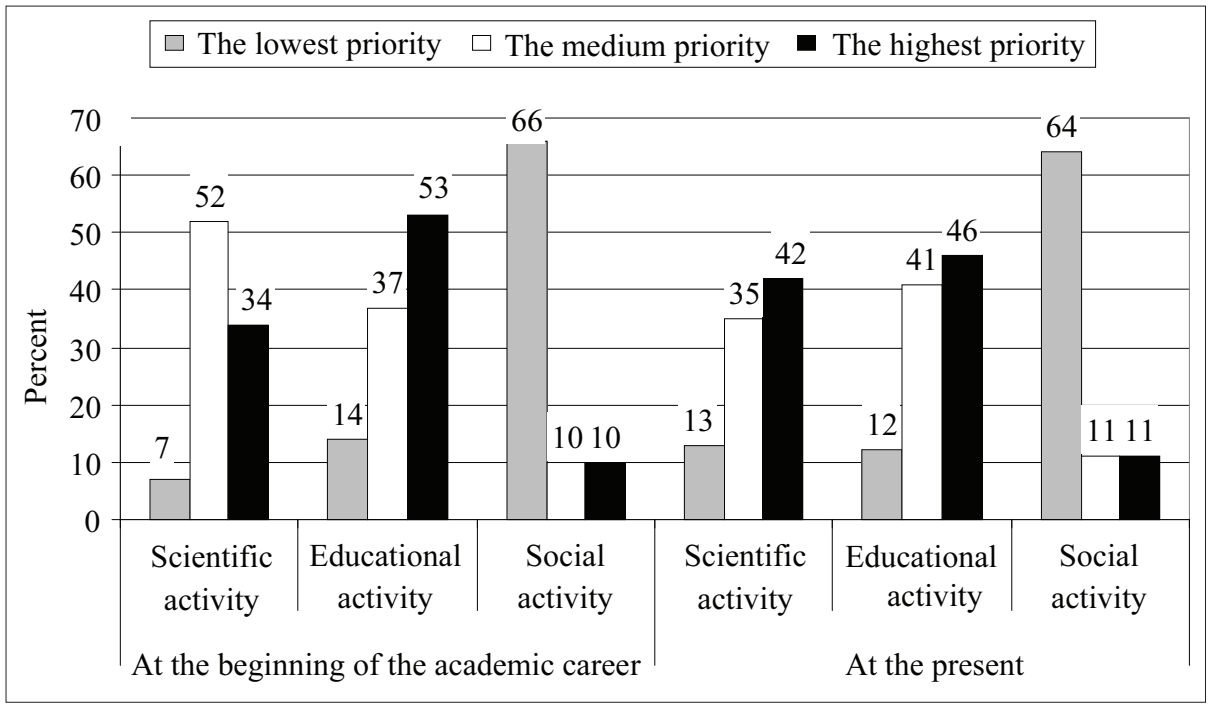

of university employees that they should be involved in discussions on various issues in other governmental institutions. Half of the respondents fully agreed with the statement that university employees depending on their competence should collaborate with representatives of local government. The statement was less emphasized by the teachers at the Lithuanian Academy of Physical Education $(I=0.60)$ in comparison with physical education teachers of other universities $(I=0.61)\left(\div^{2}=8.9(3) ; p=0.02\right)$. Almost half of participants claimed that it was very important to train specialists who are able to critically evaluate and discuss issues with people in power. Only one third of the teachers at the Lithuanian Academy of Physical Education tended to encourage students to contribute to the life of the local community.

Figure 4 represented to what kind activities priorities were given at the beginning of the respondents' pedagogical - research work and how these priorities changed teachers' functions.

More than half of the respondents (61\%) said that priorities of their professional functions changed with years of their professional experience. More than half of the current Lithuanian university physical education teachers said that their strength was the educational activity (63\%). A quarter of them said that it was their scientific activity $(20 \%)$. Almost the same number of subjects indicated that their strength was in their social activities (23\%). Scientific activities is a growing a priority to people with master's degree, but not with the doctoral degree $\left(\dot{\div}^{2}=6.6(2) ; \mathrm{p}=0.04\right)$.

\section{DISCUSSION}

Two - thirds of the present Lithuanian physical education teachers give priority to the educational activity. The priority is given for textbooks, study books, preparation for teaching materials, teaching, planning of curriculum and so on. A smaller part (one quarter) - the scientific activities: scientific research administration and article preparation, participation in conferences and social and administrative activities, participation in the governing process of the university, strategy planning, search of funds, consultation activity and so on. The research shows that the main priority of the professional career from the beginning is given to educational activity, which still exists as the main. Less priority is given to scientific and social functions. Our research confirms scientific approach that stronger focus on one or another professional function is not the result of personal individual attitudes only. It results in consensus level paradigm admitted by scientific communities: theoretical orientations, research aims and methods. A high level of consensus paradigm is specific for the communities of physical sciences, the middle level for the social sciences, while the lowest - the members of the humanities. High paradigmatic consensus societies are more orientated to research, the lower ones - to education (Austin, 1996; Neumann et al., 2002). In physical education, scientific paradigm focuses on the high consensus of natural science and on the lower consensus of sociology. Accomplished research shows that physical education teachers of practical disciplines give priority for educational activity. 
Most of physical education teachers in Lithuanian institutions of higher education agree that this is rather important that a higher school contributes to the region or the whole country's economical development. However, one-fifth of the respondents don't link their scientific activities with country's economical development. Does not pay focus on the importance of the public interests meeting. V.Zuzevičiūtèand M. Teresevičienè(2007) found that not only Lithuanian teachers but also teachers from Polish universities do not recognize links between the development of a university and the whole country. They give lower priority to above mentioned aspect, as well as to critical thinking or the formation of skills. British scientist L. Paterson's (2003) research results emphasize regional development - in England and Scotland university teachers agree that accumulated and generated knowledge in universities must benefit the society. Fundamental and applied research is considered a prior university function by physical education teachers. Traditionally it is associated with an exclusive function of universities preparation of scientists.

Our survey data are compatible with A. E. Nir and R. Zilberstein-Levy's (2006) study. It shows that aiming for a doctoral degree and going through the entrenchment period in a career (25-44 years) younger teachers give acceptable preference to an economic development, fundamental, applied and commercial research. Older teachers (45-64 years of age) going through career adapt in order to preserve their achieved positions.

University goal is not only to train researchers but professional specialists of physical education, too. Lithuanian universities organize vocational events for enlisting more motivated students. Physical education teachers positively evaluate the importance of vocational orientation events. In the point view of physical education teachers, universities should organize studies for the persons who already have completed education. The studies should be arranged to those who seek to improve or change their qualifications. This attitude shows that in a field of physical education the occurring changes are progressive. For this reason it is necessary to update professional knowledge of physical education specialists constantly. Physical education teachers underestimate the importance of academic ambitions. It depends on the type of university as well.

Each university seeks for its autonomy which ensures academic freedom. Academic freedom affects academic community as well, so members of it can openly tell their opinions about the organization and administration of the studies and scientific research, to express critical ideas. This is not only their right, but their obligation, too (Будылин, Полатайко, 2005; Westerheidjden, 2005). R. E. Stake and E. J. Cisneros-Cohernour (2004) state that although teaching is quite individual work, an institution creates its own significance. It does not matter whether loudly or quietly teacher supports the university policy or contradicts with it. Instructor supports that system which defends the university. Our study shows that one-fifth of research participants do not have an opinion about the university autonomy. One tenth of them think that autonomy is not necessary. This can be explained by the fact that during the Soviet times the link between university and the state was perverse, the dialogue between universities and society was missing (Putinaite, 2004). These deformations of academic culture can be expressed by the teachers' attitudes concerning university autonomy.

An ideologue of a higher education R. Barnett (Барнетт, 1997) understands autonomy as freedom which requires dealing with the general aims of the whole society. In the point of view of D. Churchman (2006), it is not possible to avoid some kind of a compromise in a job as a university professor. However there is not any coordination between an individual motivation and requirements of the social context. Lithuanian physical education teachers positively evaluate the statements describing their social role: teachers' activities outside the university, their roles in the education of socially active citizens capable of expressing and defending their opinions.

\section{CONCLUSIONS AND PERSPECTIVES}

The analysis of the relationship between Lithuanian university physical education teachers and the university revealed that physical education teachers carry out three core professional roles: scientific, educational, and social. The priority is given to the educational function: preparation of the text, study books, teaching materials, study programs, arranging the vocational training events, updating professional knowledge.

As we know physical education teachers underestimate the connection between their professional activity and the development of the country's economy. For this reason they 
underestimate the necessity of the preparation of research methodologies and innovations for commerce. They are more orientated to the applied investigations and less to the fundamental research.
Fundamental investigations are the priority for the teachers holding master's degree. The teachers' role is the education of socially active citizens capable of expressing and defending their opinions.

\section{REFERENCES}

Austin A. E. (1996). Institutional and departmental cultures: The relationship between teaching and research. New Directions for Institutional Research, 90, 57-66.

Becher, T. (1989). Academic Tribes and Territories. Buckingham: Open University Press/SRHE.

Braskamp, L. A., Ory, J. C. (1994). Assessing Faculty Work. San Francisco: Jossey-Bass Publishers.

Braxton, J. M., Hargens, L. L. (1996). Variation among academic disciplines: Analytical frameworks and research. In J. C. Smart (ed.), Higher Education: Handbook of Theory and Research, Vol. XI. New York: Agathon Press.

Churchman, D. (2006). Institutional Commitments, Individual Compromises: Identity-related responses to compromise in an Australian university. Journal of Higher Education Policy and Management, 28 (1), 3-15. Harris, S. (2005). Rethinking academic identities in neo-liberal times. Teaching in Higher Education, 10 (4), 421-433.

Kardelis, K., Šukys, S., Ušeckienė, L., Ališauskienė, R. (2007). Aukštujų universitetinių mokyklų dėstytojų požiūrio i institucijos veiklą ir akademines vertybes raiška. Pedagogika, 87, 33-41.

Krabi, K. (2005). University teacher's professional identity and its construction. VII International Summer School in Lifelong Learning. Roskilde University.

Kuhn, T. S. (1962). The Structure of Scientific Revolutions ( $1^{\text {st }}$ ed.). Chicago: University of Chicago Pr.

Kuhn, T. S. (1970). The Structure of Scientific Revolutions ( $2^{\text {nd }}$ ed.). Chicago: University of Chicago Pr. Neumann, R., Sharon, P., Becher, T. (2002). Teaching and learning in their disciplinary contexts: A conceptual analysis. Studies in Higher Education, 27, 4.

Nir, A. E., Zilberstein-Levy, R. (2006). Planning for academic excellence: Tenure and Professional considerations. Studies in Higher Education, 5 (31), 537-554.

Nixon, J. (1996). Professional Identity and the restructuring of higher education. Studies in Higher Education, 21 (1), 5-10.

Paterson, L. (2003). The survival of the democratic intellect: Academic values in Scotland and England. Higher Education Quarterly, 1 (57), 69-93.

Poderys, J. (2002). Sporto mokslas: mokslo funkcijos ir sporto mokslo plètra Lietuvoje. Sporto mokslas, 2 (28), 2-6.

Poderys, J., Visagurskienė, K. (2004). Sporto mokslo formavimosi ypatumai pagal modeli „,Praeitis-dabartisateitis“. Ugdymas. Kūno kultūra. Sportas, 3 (53), 11-17. Putinaitè, N. (2004). Ar Lietuvos universitetai turi pilietinę misiją? Pilietinis švietimas ir politinis raštingumas Lietuvoje: Kokiq valstybę ir visuomenę turésime?: konferencijos pranešimu medžiaga. Vilnius: Pilietinès visuomenès institutas.

Scheff, T. J. (1995). Academic gangs. Crime, Law, and Social Change, 23, 157-162.

De Simone, D. M. (2001). Identity of the university professor is formulated overtime requiring selfdiscovery followed by being an intellectual scholar and teacher. Education, Winter, 283-295.

Skurvydas, A. (2008). Senasis ir naujasis mokslas: paradigmos, metodologijos, teorijos, desniai, principai, politika. Vilnius.

Skurvydas, A. (1996). Sporto mokslas - kas tai? Sporto mokslas, 2, 10-14.

Stake, R. E., Cisneros-Cohernour, E. J. (2004). Dėstymo kokybė aukštojoje mokykloje. Aukštojo mokslo kokybe், $1,94-117$.

Stake, R. E. (1998). Teacher evaluation. Research Report No. CRAME 98-01. University of Illinois.

Šukys, S., Kardelis, K., Skurvydas, A. (2006). LKKA dèstytojų vertybinių orientacijų ir požiūrio i akademiją raiška aukštojo mokslo santykiu su visuomene raidos kontekste. Ugdymas. Küno kultūra. Sportas, 1 (60), 63-71. Tamošauskas, P. (2007). Kūno kultūros raidos tendencijos lietuvos universitetinèse aukštosiose mokyklose. Santalka. Edukologija, 15 (2), 80-87.

Välimaa, J. (1998). Culture and identity in higher education research. Higher Education, 36 (2), 119-138.

Van Voorhis, W. C., Morgan, L. B. (2001). Statistical rules of thumb: What we don't want to forget about sample sizes. Psi Chi Journal of Undergraduate Research, 6 (4), 139-141.

Westerheijden, D. (2005). Judančio taikinio link: aukštojo mokslo kokybès užtikrinimas Europoje. Aukštojo mokslo kokybè, 2, 52-71.

Ylijoki, O.-H. (2000). Disciplinary Cultures and the Moral Order of Studying - A case-study of four Finnish university departments. Higher Education, 39 (3), 339362

Zuzevičiūtè, V., Teresevičienė, M.(2007). Universitetinès studijos mokymosi visq gyvenima perspektyvoje: monografija. Kaunas: VDU.

Барнетт, Р. (1997). Осмысление университета. Материаль инаугурационной профессорской лекции, прочитанной 25 октября в Институте образования Лондонского университета. Лондон.

Будылин, Д. Ю., Полатайко, С. В. (2005). Онтологический анализ университетского идеала. История университетского образования в России и международные традиции просвещения, 2/29, 114127. Москва. 


\title{
KŪNO KULTŪROS DE்STYTOJŲ SANTYKIS SU UNIVERSITETU KAIP MOKSLINE, EDUKACINE IR VISUOMENINE INSTITUCIJA
}

\author{
Giedrè Rastauskiené1, Vilija Kriauzaité2 ${ }^{2}$, Ilona Tilindiené $\dot{e}^{1}$ \\ Lietuvos kūno kultūros akademija ${ }^{l}$, Kaunas, Lietuva \\ Lietuvos sveikatos mokslu universitetas ${ }^{2}$, Kaunas, Lietuva
}

\begin{abstract}
SANTRAUKA
Tyrimo pagrindimas ir hipotezė. Akademinè aplinka ipareigoja universiteto dèstytoją derinti tris esmines profesines funkcijas (mokslinę, edukacinę, visuomeninę) ir igyti tokią profesinę savivoką, kuri yra patraukli pačiam asmeniui, issišaknijusi akademinès bendruomenès kultūriniame suvokime ir atitinka šiandieninès visuomenès lūkesčius. Žinant, kad mokslo praktika suinteresuotų bendruomenių santykị su socialine aplinka suformuoja tikrovès pažinimo būdai, šiuo tyrimu bandyta gilintis ị kūno kultūros mokslo srities akademinès bendruomenès nuostatas.

Tikslas - atskleisti Lietuvos aukštujų mokyklų kūno kultūros dėstytoju profesini santykị su universitetu kaip moksline, edukacine ir visuomenine institucija.

Metodai. Rengdami nestandartizuotą tyrimo klausimyną rèmėmės L. Paterson (2003) demokratinio intelektualizmo raiškos Škotijos ir Anglijos universitetuose tyrimu. Šios autorès požiūrị papildème savo teiginiais. Tiriamuju nuostatos buvo interpretuotos neparametrinès statistikos metodais, gilintasi į mokslo laipsnio ir aukštojo mokslo istaigos profilio itaką.

Rezultatai. Atliktas tyrimas rodo, kad pagrindiniu profesinès veiklos prioritetu profesinès karjeros pradžioje buvo ir išlieka edukacinè veikla. Menkesnis prioritetas teikiamas mokslinei ir visuomeninei funkcijoms.

Aptarimas ir išvados. Lietuvos aukštujų mokyklų praktiniu kūno kultūros disciplinų dèstytojai, derindami esmines profesines funkcijas (mokslinę, edukacinę, visuomeninę), prioritetą teikia edukacinei funkcijai (vadovèlių, studijų knygų, mokomosios medžiagos rengimui, desstymui, studiju programų rengimui, profesinio kryptingumo akcijų rengimui, studentų bendrujų kompetencijų ir ambicingumo ugdymui, profesiniųžinių atnaujinimui baigusiems aukštojo mokslo studijas asmenims) ir orientuojasi i taikomojo pobūdžio tyrimus, susijusius su moksline universiteto funkcija - mokslo daktarų rengimu.
\end{abstract}

Raktažodžiai: aukštasis mokslas, mokslo profilis, universiteto dèstytojo profesinės funkcijos.

Gauta 2011 m. liepos16 d.

Received on July 16, 2011

Priimta 2011 m. gruodžio $8 \mathrm{~d}$.

Accepted on December 8, 2011

Corresponding author Giedrè Rastauskienè Lithuanian Academy of Physical Education Sporto str. 6, LT-44221 Kaunas

Lithuania

Tel +37068672718

E-mail g.rastauskiene@lkka.lt 